\title{
DINAMIKA PENGARUSUTAMAAN GENDER PADA PENDIDIKAN TINGGI ISLAM
}

\author{
Thohir Yuli Kusmanto \\ Universitas Islam Negeri Walisongo Semarang \\ e-mail: thohiryuli@walisongo.ac.id
}

\begin{abstract}
Abstrak
Gender equality has not been realized in practical terms in public life. Factors that influence it; socio-cultural, political, economic, religious, and others. State policy to overcome them on gender mainstreaming in the form of Presidential Decree 9 of 2000. Praxis has lasted 14 years, socialization and implementation is mostly done, but it needs evaluation. The reality of interesting research in higher education institutions of Islam, because the discourse and praxis which is still being debated, as well as the strategic position for the development and application of knowledge about gender relations. Interesting problem include; outlook leaders Islamic State University Walisongo on gender mainstreaming, the implementation of gender mainstreaming and its implications in the campus environment. This research is a qualitative descriptive case study with a gender perspective, which identifies the gender gap in multi aspect. The study's findings indicate that the views of leaders there Walisongo UIN integral and partially on gender mainstreaming, Implementation PUG; there is a policy that opens the academic community to gain an important position in the hierarchy structure at UIN Walisongo. Research take gender issues openly and freely. Many women researchers examined a variety of themes, education and training to strengthen the capacity of women, and quantitative mapping of gender. PUG strengthen the struggle gender equality, achieving gender equality and equity at a certain level, Islamic lectures Gender Equality and the proportion of women increased structural served.
\end{abstract}

Keadilan gender secara praksis belum terwujud dalam kehidupan masyarakat. Faktor yang mempengaruhinya; sosial budaya, politik, ekonomi, agama, dan lain-lainnya. Kebijakan negara untuk mengatasinya diantaranya tentang gender mainstreaming (pengarusutamaan gender), berupa Inpres No.9 Tahun 2000. Praksisnya telah berlangsung 14 tahun, sosialisasi dan implementasi banyak dilakukan, tetapi perlu evaluasi. Realitas tersebut menarik penelitian pada lembaga pendidikan tinggi Islam, karena wacana dan praksis yang masih menjadi perdebatan, serta posisinya strategis 
bagi pengembangan dan penerapan ilmu pengetahuan tentang relasi berkeadilan gender. Temuan penelitian menunjukkan bahwa pandangan pimpinan UIN Walisongo ada yang integral dan parsial tentang pengarusutamaan gender, Implementasi PUG; ada kebijakan yang terbuka civitas akademika untuk meraih posisi penting dalam struktur hierarkhi di UIN Walisongo. Penelitian mengambil isu gender terbuka dan bebas. Banyak peneliti perempuan meneliti beragam tema, pendidikan dan pelatihan penguatan kapasitas perempuan, dan pemetaan kuantitatif tentang gender. PUG memperkuat perjuangaan kesetaraan dan keadilan gender, tercapainya kesetaraan dan keadilan gender pada tingkatan tertentu, perkuliahan Islam Kesetaraan Gender dan proporsi perempuan menjabat struktural meningkat.

Kata Kunci: pengarusutamaan gender; gender; UIN Walisongo

\section{A. Pendahuluan}

Ketidakadilan gender hingga saat ini masih menjadi isu yang hangat untuk diperbincangkan dan dikaji secara akademik. Wacana tersebut masih relevan karena secara praksis belum sepenuhnya keadilan gender terwujud dalam kehidupan masyarakat. Problem-problem sosial masih sangat banyak terjadi karena relasi gender yang timpang dalam masyarakat. Masalah tersebut berlangsung pada aras domestik hingga publik.

Ketimpangan terjadi sebagai akibat dari eksistensi perempuan tersubordinasi dalam ruang publik maupun domestik. Persepsi-persepsi dasar nilai budaya yang menstereotypekan perempuan pada status dan peran yang terbatas masih sangat banyak. Potensi yang dimiliki perempuan terminimalisir karena terbatasi kesempatan untuk mengaktualisasikan dirinya. Mereka hanya diberi ruang yang sempit yaitu domestik. Domestifikasi melemahkan posisi tawarnya dalam relasi dengan laki-laki terkait dengan banyak aspek dalam kehidupan. Hal ini memperkuat ketertindasan perempuan di masyarakat. Konteks kekinian memang telah berubah. Perempuan mulai mendapatkan tempat yang setara dengan laki-laki, semuanya diperoleh melalui perjuangan yang cukup panjang. Namun demikian dalam kenyataannya belum maksimal karena perubahan sistem masih setengah-setengah, terbukti masih banyak korban perempuan dalam relasinya dengan laki-laki dalam berbagai bentuk.

Masalah ketimpangan gender merupakan sesuatu yang kompleks, karena ia melibatkan emosional setiap anggota masyarakat. Upaya untuk memperjuang- 
kan keadilan gender di masyarakat, tidak sedikit memunculkan kontra atau perlawanan. Terutama datang dari kelompok masyarakat yang selama ini mendapatkan keuntungan atau keistimewaan dari struktur sosial yang timpang tersebut. Apalagi persoalan gender memiliki spektrum atau dimensi yang luas. Persoalan gender bergerak dari diri individu sebagai pola pikir dan keyakinan, hingga pada wilayah negara. ${ }^{1}$ Persoalan gender terkait dengan masalah psikologis, biologis, sosiologis, teologis, politis dan ekonomi. Oleh karenanya perjuangan untuk keadilan gender secara makro, harus memperhatikan dimensidimensi tersebut. Pengarusutamaan gender penting dilakukan untuk mengurai benang kusut ketimpangan gender dari dimensi pembangunan. Dimensi ini memiliki makna strategis, karena proses-proses sosial yang berlangsung dalam kehidupan masyarakat tidak bisa lepas dari pengaruh pembangunan.

Kebijakan negara dan implementasinya terkait dengan program kesetaraan gender sangat banyak, berlangsung pada berbagai level kelembagaan. Pada masa reformasi pandangan negara tentang masalah ketidakadilan dan kesetaraan gender berkembang seiring dengan dinamika masyarakat. Ada perubahan mendasar dalam kebijakan negara, karena melihat kurang maksimalnya program pemberdayaan wanita sebelumnya. Untuk maka diterbitkanlah pada Inpres No. 9 Tahun 2000, tentang gender mainstreaming (pengarusutamaan gender) dalam rangka pemberdayaan perempuan menuju keadilan dan kesetaraan gender dalam berbagai elemen masyarakat. Inpres tersebut menjadi arah kebijakan pemerintah dalam rangka pemberdayaan perempuan menuju keadilan dan kesetaraan gender.

Berdasarkan pada Inpres No. 9 Tahun 2000, semua goverment agency diinstruksikan untuk memainstreamkan gender perspektif dalam semua program mereka. Sedang dalam bidang kekerasan terhadap perempuan, program tersebut diikuti dengan kebijakan Zero Tolerance Policy (kebijakan yang tidak mentolelir segala bentuk dan sekecil apapun kekerasan terhadap perempuan), yang dideklarasikan di Jakarta pada tanggal 24 November 2000, bertepatan dengan peringatan Hari Internasional untuk Anti Kekerasan terhadap Perempuan, yang

${ }^{1}$ Riant Nugroho, Gender dan Administrasi Publik: Studi tentang Kualitas Kesetaraan Gender dalam Administrasi Publik Indonesia Pasca Reformasi 1998 - 2002 (Yogyakarta: Pustaka Pelajar, 2008), h. 147. 
ditandatangani oleh departemen/instansi terkait yakni Menteri Kesehatan, Kepala Kepolisian Republik Indonesia, Menteri Kehakiman dan HAM, Menteri Koordinator Kesejahteraan Rakyat, Menteri Sosial dan Kementerian Pemberdayaan Perempuan. ${ }^{2}$

Kebijakan negara dalam bentuk gender mainstreaming telah 14 tahun lebih berlangsung. Sosialisasi dan implementasi dalam kehidupan bermasyarakat dan bernegara telah dilakukan. Berbagai pihak dilibatkan, baik lembaga pemerintah, swasta maupun organisasi kemasyarakatan. Namun demikian evaluasi atas keberhasilan sosialisasi dan implementasi atas pengarusutamaan gender sangat penting untuk dilakukan. Terutama untuk melihat tingkat keseriusan semua pihak dalam program, implementasi program yang dilaksanakan dan tingkat keberhasilannya dalam mewujudkan keadilan gender di kelembagaan pemerintah dan masyarakat.

Untuk menelisik dinamika yang ada, maka penulisan artikel ini memfokuskan pada kebijakan-kebijakan yang dibuat oleh pimpinan pengelola pendidikan tinggi agama Islam, telah responsif gender atau belum. Bagian dari upaya memahami persoalan tersebut maka akan melihat produk-produk kebijakan, implementasi dan respon publik kampus atas kebijakan tersebut, pola pembagian tanggungjawab dan wewenang serta pembagian kerja berdasar data pilah gender.

Tema penelitian pada wacana dan praksis kesetaraan gender masih hangat berlangsung di lembaga pendidikan tinggi Islam. Apalagi faktor-faktor keagamaan merupakan variabel yang sangat penting bagi upaya perubahan sosial menuju kehidupan masyarakat yang berkeadilan gender. Resistensi dan dukungan saling bertautan, sehingga mempengaruhi tingkat keberhasilan pengarusutamaan gender. Dimensi-dimensi kebijakan dan realisasinya yang berkeadilan gender, mengalir pada ranah peran dan fungsi pendidikan tinggi Islam di masyarakat. Kemudian terintegrasi dalam struktur kelembagaan, yang terpolarisasi ke dalam spesialisasi keilmuan. Dinamika keilmuan yang menjadi fokus kajian dan aktor penggeraknya akan mempengaruhi warna dari wacana dan praksis tentang keadilan gender. Akibatnya tingkat penerapan dan pencapaian dari upaya mengintegrasikan isu gender dalam segala proses pendidikan akan berbeda-beda.

${ }^{2}$ ILO, Strategi Pengarusutamaan Gender-ILO Jakarta 2003-2005 (Jakarta, Kantor Perburuhan Internasional, 2003), h. 7. 
Perempuan secara fisiologis memang mempunyai karakteristik yang berbeda dengan laki-laki yang merupakan fitrahnya sebagai makhluk Tuhan. Namun cara pandang tersebut berkembang menjadi dasar pembedaan status dan perannya di masyarakat. Pembedaan tersebut mendapatkan legitimasi dalam nilai-nilai, norma, adat istiadat, dan sistem sosial budaya. Perempuan diposisikan sebagai orang nomor dua. Akibat cara pandang tersebut berkembang persepsi bahwa perempuan kedudukannya lebih rendah. Akibatnya mereka mendapatkan perlakuan tidak adil, timpang, dan tersubordinasi. Realitas ini mengalir terus menerus dalam ruang dan waktu yang lebih luas dan lama, sebagai konsekuensi dari rekonstruksi yang mengembang dalam berbagai varians.

\section{B. Keadilan dan Ketidakadilan Gender}

Keadilan Gender adalah suatu proses untuk menjadi adil terhadap laki-laki dan perempuan (Impres, 2000). ${ }^{3}$ Keadilan gender bisa tercipta secara luas dalam kehidupan masyarakat. Proses sosialisasi yang kuat dan massif tentang pentingnya keseteraan gender harus selalu dilakukan. Untuk mendukung keduanya maka perlu beberapa cara yaitu: ${ }^{4}$ 1) Pembakuan istilah gender dengan mendasarkan pada kondisi masyarakat sebagai suatu tradisi, yang memuat aspek sosial budaya, ekonomi, dan politik dalam mengakses berbagai elemen pembangunan. 2) Pemahaman pendekatan analisis gender, yang tidak hanya sebagai pembedaan secara biologis atau seks (laki-laki atau perempuan) atau sifat perseorangan (maskulin atau feminin). Tetapi berdasarkan atas perspektif dalam dimensi sosial budaya. 3) Pendekatan pembangunan dilakukan dengan pertimbangan bahwa perbedaan peran gender dan ketergantungan antara laki-laki dan perempuan sebagai sesuatu yang bisa diubah dan mengalami perubahan sesuai kondisi sosial budaya masyarakat.

Keadilan gender dalam masyarakat bisa tercapai, jika ada perjuangan untuk merubah kondisi dan perbaikan posisi kaum perempuan. Perjuangan ini bukanlah sebagai upaya kaum perempuan melawan laki-laki. Namun sebagai upaya membongkar akar persoalan ketimpangan gender yang diperkuat oleh sistem

\footnotetext{
Nasional.

${ }^{3}$ Inpres No. 9 Tahun 2000 tentang Pengarus Utamaan Gender dalam Pembangunan

${ }^{4}$ Dadang S. Anshori, Membincangkan Feminisme: Refleksi Muslimah atas Peran Sosial Kaum Wanita Bandung (Bandung: Pustaka Hidayah, 1997), h. 66-67.
} 
dan struktur sosial masyarakatnya. Ada dua bentuk perjuangan yang memiliki implikasi strategis dan luas yaitu: 1) Mendekonstruksi ideologi yang hegemonik yang merendahkan dan menindas perempuan. Perjuangan untuk mempertanyakan kembali kondisi yang mempengaruhi nasib perempuan. Akhirnya terbangun kesadaran kritis atas gender; 2) Melawan paradigma developmentalisme, yang menganggap keterbelakangan kaum perempuan karena tidak berpartisipasinya perempuan dalam pembangunan. ${ }^{5}$ Perempuan cenderung diposisikan sebagai objek pembangunan. Untuk itu maka perempuan diidentifikasi, diukur, dan diprogram dalam rangka pembangunan.

Ketidakadilan gender dalam masyarakat bisa dijelaskan dalam kerangka struktur dan kultur masyarakat. Keduanya saling terkait dalam memperkuat kehidupan masyarakat yang tidak adil. Oleh karenanya ada tiga faktor penyebab; Pertama) adanya ketimpangan gender di masyarakat. Konstruksi sosial (kultur) menjadi penyebab utama terjadinya ketimpangan gender. Faktor ini mencirikan (memberi sifat) tertentu kepada laki-laki dan wanita secara berbeda. Pencirian tersebut meliputi; sifat wanita lemah lembut, bertanggung jawab terhadap keluarga sebagai pelayan suami dan sebagainya, yang menjadikannya sebagai anggota masyarakat kelas kedua. Kedua) kebudayaan (warisan) feodal yang masih mencengkeram wanita. Pada budaya feodal wanita hanya sebagai pembantu suami, sebagai simbol kekuasan aristokrat, wanita sebagai pendukung aktifitas suami dalam menjalankan peran sosialnya. Ketiga) akibat adanya tekanan ekonomi, berupa distribusi akses-akses ekonomi (produksi) yang meminggirkan perempuan. Wanita sulit untuk mengakses berbagai sumber ekonomi. Meskipun industrialisasi telah membuka berbagai sumber ekonomi yang lebih banyak dan luas. Industrialisasi telah merubah sistem ekonomi masyarakat yang semula agraris menuju industri, sehingga mengubah cara produksi dalam masyarakat. Peran wanita terpinggirkan dalam sistem ekonomi industri bahkan hilang sama sekali, karena mereka tidak mampu ikut serta dalam proses industrialisasi yang menuntut ketrampilan dan pendidikan yang lebih. ${ }^{6}$

${ }^{5}$ Riant Nugroho, Gender dan Administrasi Publik..., h. 151-152.

${ }^{6}$ Budi Wahyuni, Terpuruk Ketimpangan Gender (Yogyakarta: LAPERA Indonesia dan PKBI DIY, 1997), h. 2.-4. 


\section{Pengarusutamaan Gender}

Pengarusutamaan gender merupakan suatu strategi dalam rangka meningkatkan kedudukan, peran, dan kualitas perempuan, serta upaya mewujudkan kesetaraan dan keadilan gender dalam kehidupan berkeluarga, bermasyarakat, berbangsa, dan bernegara. Pengarusutamaan gender dilaksanakan dalam seluruh proses pembangunan nasional. Sebagai proses yang berlangsung dalam seluruh proses pembangunan, maka pengarusutamaan gender merupakan bagian yang tidak terpisahkan dari kegiatan fungsional semua instansi dan lembaga pemerintah di tingkat Pusat dan Daerah.7

Pengarusutamaan gender (gender mainstreaming) merupakan konsep global, tetapi merupakan bagian dari wacana dan aksi global. Perkembangannya di Indonesia merupakan bagian dari wacana dan aksi global. Pertama kali sebagai konsep, gender mainstreaming muncul dalam Konferensi Perempuan Dunia yang ketiga di Nairobi Kenya tahun 1985. Penyelenggara konferensi tersebut adalah Perserikatan Bangsa-Bangsa (PBB). Sebagai sebuah konsep gender mainstreaming, merupakan produk dari perdebatan panjang dari partisipan konferensi terutama Commission on the Status of Women (CSW). Pengarusutamaan gender muncul sebagai upaya mengintegrasikan perempuan dalam pembangunan. Nilai-nilai yang terkait dengan perempuan harus diperkuat sebagai bentuk dukungan dan upaya mengintegrasikannya dalam pembangunan. ${ }^{8}$

Wacana gender mainstreaming memperoleh penguatan dalam Konferensi Perempuan Dunia keempat yang berlangsung di Beijing China tahun 1995. Dalam konferensi ini partisipan menegaskan kembali tentang pentingnya gender mainstreaming. Partisipan konferensi menuntut pemerintah selaku pemegang kebijakan, agar dalam menyusun rencana kebijakan dan implementasi program pembangunan agar secara aktif memasukkan perspektif gender di dalamnya. Sebagai tahap awal, perlu adanya 'gender wacth' yang berperan untuk memeriksa, dan mengevaluasi berbagai kebijakan, program dan implikasi pembangunan bagi laki-laki dan perempuan. ${ }^{9}$ Nasional.

${ }^{7}$ Inpres No. 9 Tahun 2000 tentang Pengarus Utamaan Gender dalam Pembangunan

${ }^{8}$ Riant Nugroho, Gender dan Administrasi Publik..., h. 141.

${ }^{9}$ Ibid., h. 141-142. 
Pengarusutamaan gender dalam seluruh proses pembangunan akan berhasil, jika mendasarkan analisis gender yang mendalam. Analisa gender merupakan suatu upaya memetakan/mengidentifikasi dan mememahami ada atau tidak adanya dan sebab-sebab terjadinya ketidaksetaraan dan ketidakadilan gender, termasuk pemecahan permasalahannya. Analisa gender merupakan proses yang meliputi: 1) Mengidentifikasi kesenjangan antara laki-laki dan perempuan dalam memperoleh manfaat dari kebijakan dan program pembangunan dalam berbagai aspek kehidupan; 2) Mengidentifikasi dan memahami sebabsebab terjadinya ketidaksetaraan dan ketidakadilan gender dan menghimpun faktor-faktor penyebabnya; 3) Menyusun langkah-langkah yang diperlukan untuk mewujudkan kesetaraan dan keadilan gender; 4) Menetapkan indikator gender untuk mengukur capaian dari upaya-upaya mewujudkan kesetaraan dan keadilan gender. ${ }^{10}$

\section{Pendidikan Tinggi}

Pendidikan merupakan proses sosial yang bersifat multidimensi. Berbagai aspek terlibat di dalamnya. Apalagi orientasinya yang sangat besar dalam mengembangkan potensi sumber daya diri bagi peserta didiknya. Penyelengaraannya menjadi tanggung jawab semua elemen masyrakat. Negara merupakan elemen penting dalam proses ini. Untuk menegaskan peran negara dalam pendidikan, maka negara merumuskan konsepsi pendidikan dalam peraturan perundangundangan. Menurut negara, pendidikan adalah usaha sadar dan terencana untuk mewujudkan suasana belajar dan proses pembelajaran agar peserta didik secara aktif mengembangkan potensi dirinya untuk memiliki kekuatan spiritual keagamaan, pengendalian diri, kepribadian, kecerdasan, akhlak mulia, serta keterampilan yang diperlukan dirinya, masyarakat, bangsa dan negara. ${ }^{11}$

Pendidikan tinggi merupakan jenjang pendidikan setelah pendidikan menengah yang mencakup program pendidikan diploma, sarjana, magister, spesialis, dan doktor yang diselenggarakan oleh pendidikan tinggi. Pendidikan tinggi diselenggarakan dengan sistem terbuka. ${ }^{12}$

\footnotetext{
${ }^{10} \mathrm{Ibid} .$, h. 141.

${ }^{11}$ Undang-Undang Republik Indonesia Nomor 20 Tahun 2003 tentang Sistem Pendidikan Nasional.

${ }^{12}$ Ibid.
} 
Pendidikan Tinggi adalah jenjang pendidikan setelah pendidikan menengah yang mencakup program diploma, program sarjana, program magister, program doktor, dan program profesi, serta program spesialis, yang diselenggarakan oleh perguruan tinggi berdasarkan kebudayaan bangsa Indonesia.

Keberadaan Pendidikan Tinggi dalam kehidupan berbangsa dan bernegara sangat strategis. Berawal dari peran pengembangan pribadi anak didiknya (mahasiswa), hingga kontribusinya bagi kehidupan praktis masyarakat yang tidak lepas dari budaya akademik. Lebih rinci berikut tujuan pendidikan tinggi di Indonesia: ${ }^{13}$ 1) Berkembangnya potensi Mahasiswa agar menjadi manusia yang beriman dan bertakwa kepada Tuhan Yang Maha Esa dan berakhlak mulia, sehat, berilmu, cakap, kreatif, mandiri, terampil, kompeten, dan berbudaya untuk kepentingan bangsa; 2) Dihasilkannya lulusan yang menguasai cabang ilmu pengetahuan dan/atau teknologi untuk memenuhi kepentingan nasional dan peningkatan daya saing bangsa; 3) Dihasilkannya ilmu pengetahuan dan teknologi melalui penelitian yang memperhatikan dan menerapkan nilai humaniora agar bermanfaat bagi kemajuan bangsa, serta kemajuan peradaban dan kesejahteraan umat manusia; dan terwujudnya pengabdian kepada masyarakat berbasis penalaran dan karya penelitian yang bermanfaat dalam memajukan kesejahteraan umum dan mencerdaskan kehidupan bangsa.

Pendidikan tinggi secara kelembagaan memiliki otoritas akademik dan administratif. Keduanya memungkinkan lembaga pendidikan tinggi tumbuh dan berkembang secara bebas, tetapi harus ada akuntabilitas publik. Upaya-upaya pengembangan keilmuan dan pengaplikasiannya dalam praktik, memiliki peluang yang luas dilakukan pendidikan tinggi. Posisi pendidikan tinggi tersebut bisa dilihat dalam peraturan perundang-undangan tentang pendidikan tinggi sebagai berikut: ${ }^{14}$ 1) Dalam penyelenggaraan pendidikan dan pengembangan ilmu pengetahuan, pada perguruan tinggi berlaku kebebasan akademik dan kebebasan mimbar akademik serta otonomi keilmuan. 2) Perguruan tinggi memiliki otonomi untuk mengelola sendiri lembaganya sebagai pusat penyelenggaraan pendidikan tinggi, penelitian ilmiah, dan pengabdian kepada Tinggi.

${ }^{13}$ Undang-Undang Republik Indonesia Nomor 12 Tahun 2012 tentang Pendidikan ${ }^{14} \mathrm{Ibid}$. 
masyarakat; 3) Perguruan tinggi dapat memperoleh sumber dana dari masyarakat yang pengelolaannya dilakukan berdasarkan prinsip akuntabilitas publik.

Pengarusutamaan gender akan efektif, jika terintegrasi dalam proses tridharma perguruan tinggi. Sebagai bagian dari kewajiban yang harus dilaksanakan oleh perguruan tinggi. Dalam undang-undang tentang pendidikan tinggi disebutkan bahwa tridharma merupakan kewajiban Perguruan Tinggi untuk menyelenggarakan pendidikan, penelitian, dan pengabdian kepada masyarakat. ${ }^{15}$ Pendidikan adalah usaha sadar dan terencana untuk mewujudkan suasana belajar dan proses pembelajaran agar peserta didik secara aktif mengembangkan potensi dirinya untuk memiliki kekuatan spiritual keagamaan, pengendalian diri, kepribadian, kecerdasan, akhlak mulia, serta keterampilan yang diperlukan dirinya, masyarakat, bangsa, dan negara. ${ }^{16}$ Penelitian merupakan kegiatan yang dilakukan menurut kaidah dan metode ilmiah secara sistematis untuk memperoleh informasi, data, dan keterangan yang berkaitan dengan pemahaman dan/atau pengujian suatu cabang ilmu pengetahuan dan teknologi. ${ }^{17}$ Pengabdian kepada masyarakat dilakukan dengan memanfaatkan ilmu pengetahuan dan teknologi untuk memajukan kesejahteraan masyarakat dan mencerdaskan kehidupan bangsa. ${ }^{18}$

\section{E. Analisa Pengarusutamaan Gender di Lingkungan Kampus}

\section{Pandangan Pimpinan UIN Walisongo tentang Pengarusutamaan Gender}

Temuan penelitian menunjukkan adanya keragaman pandangan diantara pimpinan UIN Walisongo. Pandangan tersebut terelaborasi secara hirarkhi dalam hubungan vertikal dan horisontal. Hubungan vertikal memberi gambaran posisi atasan dan bawahan, pimpinan tertinggi hingga terendah. Hubungan horisontal menunjuk pada pola yang setara antar posisi dalam struktur sosial. Pimpinan tertinggi dalam hal ini adalah rektor, kemudian wakil-wakilnya, pimpinan kelembagaan, biro, dekan, wakil-wakil dekan, dan jurusan. Pimpinan

\footnotetext{
${ }^{15}$ Ibid.

${ }^{16}$ Ibid.

${ }^{17} \mathrm{Ibid}$

${ }^{18} \mathrm{Ibid}$.
} 
yang menjadi sumber utama dalam penelitian dan bisa digali informasinya adalah Dekanat, kepala bagian, ketua lembaga, dan ketua pusat studi gender.

Keragaman pandangan mereka menunjukkan bahwa pengetahuan dan pemahamannya terkonstruk dalam diri yang berbeda. Hal tersebut sangat dipengaruhi; sejarah masa lalu kelembagaan dan personal, latar belakang pendidikan, ruang lingkup relasi kelembagaan, bacaan tekstual dan kontekstual, dan pengalaman karier akademik dan struktural. Sejarah masa lalu yang mempengaruhi pimpinan UIN tentang pengarusutamaan gender terbentuk secara kolektif-kelembagaan dan individual-personal. Pembentukan secara kolektif kelembagaan bisa dilihat dari pengaruh dari sejarah pertumbuhan dan perkembangan UIN Walisongo, dari sejak awal pendirian hingga terkini. Merujuk pada data sejarah awal pendirian UIN Walisongo, yang pada awalnya IAIN bisa ditarik benang merah bahwa sejarah kelembagaannya menunjuk pada maskulinitas. Sifat maskulinitas kelembagaan UIN bisa ditemukan dan dibaca dalam proses pembentukannya. Pihak-pihak yang terlibat dalam pembentukan IAIN yang akhirnya menjadi UIN semua laki-laki, baik mereka yang berlatar bekalang elit politik, elit keislaman, dan elit pendidikan.

Pemahaman tentang konsep atau istilah pengarusutamaan gender, tidak sepenuhnya bisa mendarah daging dalam pimpinan di kelembagaan UIN Walisongo. Mereka memandang bahwa pengarusutamaan gender merupakan kebijakan-kebijakan terkait gender. Dalam pemahaman ini kebijakan tersebut merupakan kebijakan yang datang dari pemerintah pusat atau menteri. Secara hirarkhi kelembagaan, mereka hanyalah sebagai pelaksana atas kebijakan tersebut pada aras kelembagaan yang dipimpinnya. Pimpinan UIN Walisongo memposisikan diri sebagai bawahan yang hanya melaksanakan kebijakan tersebut. Segala proses yang terkait dengan pembelajaran dan praktiknya menjadi wilayah tanggung jawab pusat. Pimpinan UIN Walisongo Semarang mengakui bahwa pengarusutamaan gender (PUG) mengalir dalam lingkungan UIN Walisongo Semarang. Namun ada juga yang memiliki pandangan yang berbeda, informan memahami bahwa PUG merupakan kebijakan pada tingkat UIN Walisongo yang diterapkan di berbagai bagian struktural kelembagaannya.

Ada pimpinan yang memahami PUG sebagai persoalan tentang kesetaraan posisi atau kedudukan laki-laki dan perempuan dimanapun. Pandangan ini memposisikan PUG sebagai proses untuk mencapai kesetaraan yang ber- 
langsung di berbagai tempat. Sebagai bentuk nyata menurut informan di fakultasnya ada upaya nyata untuk mewujudkan hal tersebut.

\section{Implementasi Pengarusutamaan Gender di Universitas Islam Negeri Walisongo}

Implementasi pengarusutamaan gender menurut informan dalam beberapa bentuk; pemberian kesempatan yang luas bagi anggota civitas akademika untuk bersaing meraih posisi penting di lingkungan kelembagaan yang dipimpinnya. Banyak perempuan yang mampu menduduki posisi penting, yang selama ini cenderung lebih banyak laki-laki yang mendudukinya. Kedudukan strategis yang bisa diraih perempuan misalnya; wakil dekan, ketua atau sekretaris jurusan, kepala bagian tata usaha dan lain-lainnya. Pandangan tersebut dikemukakan oleh beberapa informan terutama yang menjadi dekan pada lima fakultas di UIN Walisongo. Mereka menegaskan bahwa munculnya realitas tersebut merupakan bagian kebijakan atau upaya-upaya yang dilakukannya. Namun demikian ada dekanat yang merasa bahwa untuk mewujudkan kondisi tersebut tidaklah mudah. Ada beberapa kendala struktural yang dihadapinya, untuk mendorong perempuan agar bisa menduduki posisi yang lebih strategis dari yang sudah diraih dalam struktur hirarkhi kelembagaan yang dipimpinnya.

Kendala struktural tersebut yaitu masih rendahnya kepangkatan dari perempuan yang potensial untuk maju di lingkungan kelembagaannya. Oleh karena dalam sistem struktur kelembagaan di UIN Walisongo ada prasyarat formal, agar seseorang bisa menduduki posisi penting dalam struktur kelembagaan yaitu kepangkatan seseorang.

Implementasi pengarusutamaan gender berupa pemberian kesempatan yang sama dan seluas-luasnya bagi laki-laki dan perempuan di kelembagaan yang dipimpinnya. Perempuan sedikit yang mendapatkan posisi dalam struktur hierarkhi organisasi dekanat pada lima fakultas di UIN Walisongo. Kebanyakan perempuan memperoleh posisi pada tingkat jurusan dan bagian administrasi fakultas. Persyaratan formal yang belum terpenuhi oleh perempuan di beberapa fakultas menjadi penentu. Persyaratan tersebut adalah kepangkatan (golongan) dari personal perempuan. Meskipun secara kelembagaan pihak dekanat memberikan kesempatan dan mendorong mereka untuk masuk dalam struktur yang tinggi (tingkat dekanat). Hanya di Fakultas Ushuludin yang memiliki wakil dekan perempuan, empat fakultas yang lainnya tidak ada. 
Implementasi dari pengarusutamaan gender bisa dilihat dalam penerapan tri dharma perguruan tinggi. Temuan penelitian menunjukkan bahwa ada kesempatan yang sama antara laki-laki dan perempuan dalam aktifitas pendidikan, penelitian dan pengabdian masyarakat. Pengintegrasian tersebut dilihat sebagai proses untuk pengembangan intelektualitas sumber daya manusia perempuan. ${ }^{19}$ Menurut salah satu informan, tahap yang paling awal dengan menyusun rencana program yang tidak membeda-bedakan jenis kelamin. Tahapan ini merupakan bagian dari bentuk kepedulian atas kesetaraan gender di UIN Walisongo. Bagian perencanaan berkompeten tentunya. Namun temuan penelitian menyebutkan bahwa peran perencaan hanya mengintegrasikan dan menyelaraskan rencana unit-unit dan lembaga tanpa menyinggung gender sedikitpun. Fungsinya agar bisa meningkatkan kompetensi dan skill para civitas akademik UIN Walisongo. ${ }^{20}$

Pentingnya pengintegrasian PUG dalam kewajiban tri dharma (pendidikan, penelitian, dan pengabdian masyarakat) dikemukakan informan yang lain. Dekan Fakultas Ushuludin menyatakan bahwa kami memasukkan beberapa penelitian tentang gender yang dipadukan dengan nilai-nilai Islam dan ada pula dalam perkuliahan mahasiswa. Upaya tersebut merupakan bukti antusiasme secara kelembagaan di Fakultas Ushuludin terhadap persoalan gender di UIN Walisongo. ${ }^{21}$

Penelitian-penelitian yang diadakan UIN Walisongo telah mengakomodasi gender sebagai isu utama atau gender dalam konteks pelaku. Meskipun temuan menunjukkan penelitian dengan mengangkat persoalan gender sangat sedikit, dibandingkan penelitian non gender. Kemungkinannya ada beberapa penyebab; penguasaan atas isu-isu gender masih terbatas pada sebagian dosen dan mahasiswa. Baik bersifat umum maupun yang berkaitan dengan bidang keilmuan yang ditekuninya. Dalam rentang tiga tahun (2012-2014) jumlah penelitian yang mengusung isu gender hanya 11 judul penelitian atau $5,73 \%$ dari

\footnotetext{
${ }^{19}$ Data berdasarkan hasil wawancara dengan ketua LP2M pada hari Senin, 29 Juni 2015 jam 08:46 di Kantor LP2M UIN Walisongo.

${ }^{20}$ Data berdasarkan hasil wawancara dengan Kepala bagian perencanaan, pada hari Senin, 8 Juni 2015 jam 09:49 di Kantor Kabag. Perencanaan UIN Walisongo.

${ }^{21}$ Data berdasarkan hasil wawancara dengan Dekan Fakultas Ushuludin pada hari Kamis, tanggal 25 Juni 2015, jam 13:04 di Kantor Dekanat.
} 
total penelitian 192 judul penelitian. Penelitian non gender ada 181 judul penelitian atau $94,27 \%{ }^{22}$ Jumlah tersebut untuk kepentingan pengarusutamaan gender merupakan jumlah yang sedikit. Peningkatkan jumlah penelitian yang mengusung tema gender dengan mengupayakan penguatan kapasitas civitas akademika.

Dalam rentang waktu tiga tahun (2012 - 2014) jumlah peneliti laki-laki 163 orang atau 72,76\%, jumlah peneliti perempuan 61 orang atau 27,24\%. Perbandingan jumlah tersebut tentu masih rendah jika mengacu pada konsep partisipasi politik perempuan dalam kegiatan politik yaitu kuota 30\% atau proporsi jumlah PNS di UIN yang sudah di atas 30\% . Kondisi tersebut tentu menjadi pekerjaan rumah bagi civitas akademika UIN Walisongo Semarang. Perlu upaya mendorong dan meningkatkan kapasitas perempuan dalam aktifitas penelitian.

Penguatan kapasitas melalui pelatihan dan workshop menjadi sarana implementasi pengarusutamaan gender. Keduanya dilakukan dalam rangka memperkuat keterampilan dan pengetahuan isu-isu terkait dengan gender ataupun isu-isu yang tidak terkait dengan gender. Untuk kegiatan pelatihan dan workshop yang tidak bersinggungan langsung dengan isu gender, perlu memperhatikan komposisi peserta yang proporsional berdasarkan gender. Kegiatan ini diantaranya; workshop metodologi penelitian, workshop pengembangan kurikulum jurusan, workshop metode pembelajaran, workshop penulisan karya ilmiah untuk jurnal internasional, dan lain-lain.

\section{Implikasi dari Pengarusutamaan Gender pada Keadilan Gender}

Implikasi dari pengarusutamaan gender sangat beragam menurut pimpinan UIN Walisongo Semarang. Berdasarkan pengalaman yang mereka hadapi, temukan dan pengalaman yang dirasakan. Beberapa informan merasa bahwa mereka berkontribusi dalam pengarusutamaan gender sehingga bisa mewujudkan keadilan gender. Namun ada juga yang merasa bahwa terciptanya kondisi kelembagaan yang dipimpinnya bisa proporsional atau berimbang dalam jumlah personalnya, bukan karena kontribusinya atau kebijakan-kebijakan yang

\footnotetext{
${ }^{22}$ Data berdasarkan dokumen tentang penerima dana penelitian DIPA IAIN Walisongo tahun 2012-2014.
} 
dibuatnya. Ada pihak lain yaitu rektorat yang menciptakan kondisi tersebut. oleh karena penempatan pegawai atau personal ditentukan sepenuhnya oleh pihak rektorat.

Pengarusutamaan gender telah mendorong informan dan kelembagaannya untuk senantiasa memperjuangkan kesetaraan gender, karena harus diakui masih ada beberapa kendala; masih adanya pandangan bias gender di kalangan civitas akademika dan masih lemahnya beberapa perempuan untuk berkompetisi dengan laki-laki. ${ }^{23}$ Personalitas perempuan menjadi penentu mereka lebih eksis dan mampu meraih posisi strategis dalam struktural kelembagaan UIN Walisongo. Ketika personalitas menjadi faktor penentu, maka akan sangat berat bagi perempuan dalam sistem sosial (kehidupan kampus) yang memiliki akar sejarah struktural yang maskulin. Perempuan mengalami kesulitan, jika ingin maju dan berkembang. Berbeda jika secara histories struktural dan fakta kekinian sistem sosial budaya kampus mendukung sepenuhnya pengembangan diri perempuan untuk lebih maju dan berkembang.

Implikasi PUG dalam proses pendidikan bisa berlangsung dalam perkuliahan. Ada beberapa mata kuliah yang menjadikannya sebagai salah satu bagian dari bahan perkuliahan. Bahkan ada kebijakan akademik pada tingkat perguruan tinggi yang menetapkan bahwa semua fakultas wajib menyelenggarakan perkuliahan Islam Kesetaraan Gender (IKG). Upaya tersebut strategis untuk menginternalisasi nilai kesetaraan gender pada mahasiswa khususnya melalui perkuliahan. Apalagi ada informan yang menegaskan bahwa isu gender berkaitan erat dengan islamic studies, ${ }^{24}$ yang merupakan inti dari materi pembelajaran di UIN Walisongo Semarang.

Implikasi bisa ditemukan juga dalam bentuk banyak dari anggota civitas akademika di lingkungan informan yang menjadi aktivis gender. ${ }^{25}$ Mereka aktif di kampus maupun di luar kampus. Menurut dekan Fakultas Dakwah dan

${ }^{23}$ Data merupakan hasil wawancara dengan Ketua Pusat Studi Gender dan Anak (PSGA), pada hari Senin, 6 Juli 2015, 11:29.

${ }^{24}$ Wawancara dengan Dekan Fakultas Ushuludin pada Kamis, 25 Juni 2015, 13:04 di Kantor Dekan Ushuluddin UIN Walisongo.

${ }^{25}$ Data hasil wawancara dengan Dekan Fakultas Dakwah dan Komunikasi UIN Walisongo Semarang, pada hari Rabu, tanggal 17 Juni 2015, jam 09:21 di Kantor Dekan FDK UIN Walisongo. 
Komunikasi berdasarkan fakta bahwa banyak dosen di fakultasnya yang menjadi aktivis dan bergerak dalam berbagai lembaga yang mengkampanyekan kesetaraan dan keadilan gender. Sebagai bukti dua periode berturut-turut ketua Pusat Studi Gender merupakan dosen FDK. Banyak dosen yang lainnya yang aktif di beberapa organisasi sosial keagamaan yang memperjuangkan kesetaraan dan keadilan gender.

Secara kuantitatif jumlah perempuan yang mampu menduduki posisi strategis terus bertambah. Ada informan yang menjelaskan bahwa di kelembagaannya (fakultas) jumlah telah mencapai $40 \%{ }^{26}$ Ada informan yang menyatakan proporsi jumlah perempuan di UIN telah mencapai angka 35\%. Peningkatan jumlah tersebut memberi sinyal bahwa ada kecenderungan positif bagi upaya menciptakan kesetaraan dan keadilan gender. ${ }^{27}$

\section{F. Kesimpulan}

Pengarusutamaan gender telah berlangsung di UIN Walisongo, di tengahtengah pemahaman konsep dan kerangka pikir tentang PUG yang terbatas dan parsial. Pimpinan UIN Walisongo memahami PUG sebagai sesuatu yang datang dari luar kelembagaannya. Mereka memandang PUG merupakan kebijakan dari pusat atau menteri. Akibatnya mereka mempersepsikan diri hanya sebagai pelaksana kebijakan tersebut. Namun demikian ada kesempatan untuk mengembangkan proses ini secara kreatif dan inovatif sesuai dengan konteks kelembagaan tempat mereka berada. Dalam struktur kelembagaan ada Pusat Studi Gender di UIN Walisongo Semarang. Sebagian pimpinan memahami bahwa persoalan PUG menjadi tanggung jawab lembaga ini dalam pengintergrasian dan implementasinya.

Implementasi PUG mewujud dalam beragam bentuk; pemberian kesempatan dan kepercayaan luas bagi perempuan mengembangkan potensi dan menduduki posisi struktural, pelaksanaan tugas pokok dan fungsi yang tidak membedakan jenis kelamin tetapi atas pertimbangan kualitas, kompetensi dan

\footnotetext{
${ }^{26}$ Data disampaikan Dekan Fakultas Ushuludin dalam wawancara pada Kamis, 25 Juni 2015, 13:04 di Kantor Dekan Ushuluddin UIN Walisongo.

${ }^{27}$ Data hasil wawancara dengan Kepala Bagian Organisasi, Kepegawaian, dan Hukum UIN Walisongo Semarang pada hari Senin, 8 Juni 2015, 13:12 di Kantor Kabag. Kepegawaian UIN Walisongo.
} 
skill, penyusunan rencana strategis yang tidak bias gender, penguatan akademik dan kualitas SDM dengan pendidikan dan pelatiahan pada aras pendidikan, penelitian dan pengabdian masyarakat. PUG telah meningkatkan kuantitas perempuan dengan posisi penting di struktur kelembagaan UIN Walisongo, integrasi isu gender dalam proses belajar mengajar, dan penguatan perjuangan kesetaraan gender ditengah-tengah masih adanya civitas akademika yang bias gender.]

\section{Daftar Pustaka}

Anshori, Dadang S., Membincangkan Feminisme: Refleksi Muslimah atas Peran Sosial Kaum Wanita Bandung, Bandung: Pustaka Hidayah, 1997.

Data Master PNS UIN Walisongo Semarang tahun 2015.

ILO, Strategi Pengarusutamaan Gender - ILO Jakarta 2003-2005, Jakarta, Kantor Perburuhan Internasional, 2003.

Nugroho, Riant, Gender dan Administrasi Publik: Studi tentang Kualitas Kesetaraan Gender dalam Administrasi Publik Indonesia Pasca Reformasi 1998 - 2002, Yogyakarta: Pustaka Pelajar, 2008.

, Gender dan Strategi Pengarus-Utamaannya di Indonesia, Yogyakarta: Pustaka Pelajar, 2008.

Pusat Kajian Gender UI, Hak Azasi Perempuan: Instrumen Hukum untuk Mewrijudkan Keadilan Gender, Jakarta: Yayasan Obor Indonesia, 2007.

Silabi mata kuliah Islam dan Kesetaraan Gender di Fakultas Dakwah dan Komunikasi IAIN Walisongo semarang tahun akademik 2015 dengan dosen pengampu Dr. Moh. Fauzi, M.Ag.

Undang-Undang Republik Indonesia Nomor 20 Tahun 2003 tentang Sistem Pendidikan Nasional.

Undang-Undang Republik Indonesia Nomor 12 Tahun 2012 tentang Pendidikan Tinggi.

Wahyuni, Budi, Terpuruk Ketimpangan Gender, Yogyakarta: LAPERA Indonesia dan PKBI DIY, 1997. 
